Portland State University

PDXScholar

Communication Faculty Publications and

Presentations

Communication

$1-30-2014$

\title{
Dead Newspapers and Citizens' Civic Engagement
}

Lee Shaker

Portland State University, Ishaker@pdx.edu

Follow this and additional works at: https://pdxscholar.library.pdx.edu/comm_fac

Part of the Civic and Community Engagement Commons, Journalism Studies Commons, and the Social Influence and Political Communication Commons

Let us know how access to this document benefits you.

\section{Citation Details}

Published as: Shaker, L. (2014). Dead newspapers and citizens' civic engagement. Political Communication, 31(1), 131-148.

This Post-Print is brought to you for free and open access. It has been accepted for inclusion in Communication Faculty Publications and Presentations by an authorized administrator of PDXScholar. Please contact us if we can make this document more accessible: pdxscholar@pdx.edu. 


\section{Dead Newspapers and Citizens' Civic Engagement ${ }^{1}$ \\ Lee Shaker - Portland State University \\ Forthcoming in Political Communication}

Using data from the 2008 and 2009 Current Population Survey conducted by the United States Census, this article assesses the year-over-year change in the civic engagement of citizens in America's largest metropolitan areas. Of special interest are Denver and Seattle, where the Rocky Mountain News and Seattle Post-Intelligencer closed during the intervening year. The data from the CPS indicate that civic engagement in Seattle and Denver dropped significantly from 2008 to 2009 - a decline that is not consistently replicated over the same time period in other major American cities that did not lose a newspaper. The analysis suggests that this decline may plausibly be attributed to the newspaper closures in Seattle and Denver. This short-term negative effect is concerning and whether it lasts warrants future attention.

\footnotetext{
${ }^{1}$ Some data in this article were obtained from the University of Wisconsin Advertising Project, including media tracking data from TNSMI/Campaign Media Analysis Group in Washington, D.C. The opinions expressed in this article are those of the author(s) and do not necessarily reflect the views of the University of Wisconsin Advertising Project.
} 
For generations, scholars (Janowitz, 1968; Kaniss, 1997; Tarde, 1903; Tocqueville, 2001) have asserted that newspapers provide critical information to citizens and serve as vital watchdogs of public officials. Today, as newspapers struggle through a rocky transition from an analog past towards a digital future, the question of newspapers’ importance is especially pressing. In Paul Starr's (2011) words, "More than any other medium, newspapers have been our eyes on the state, our check on private abuses, our civic alarm systems. It is true that they have often failed to perform those functions as well as they should have done. But whether they can continue to perform them at all is now in doubt." So, as newspaper circulation dwindles and the very future of the print product is questioned, there is scholarly and public attention upon their plight. But how important are newspapers to their communities and how concerned should we be as they decline?

Using data from the 2008 and 2009 November supplements of the Current Population Survey (CPS) conducted by the United States Census, this article examines the civic engagement of citizens in the largest American metropolitan areas. The analysis compares the year-over-year change in the civic engagement of citizens in cities that lost a newspaper in the intervening year namely, Denver and Seattle - and cities that did not lose a newspaper over the same time period. The contrast over time and across cities provides unique leverage to address the questions raised above, and the CPS data indicate that civic engagement in both Seattle and Denver dropped significantly from 2008 to 2009. This decline is not consistently replicated in the other cities that are examined - even after controlling for several other alternative explanations. Though the causality of the decline in civic engagement cannot be definitively established with the CPS data, the findings of this article lend additional empirical support to what many already believed: newspapers are vital institutions in our democracy and their decline warrants our concern. 


\section{The Rocky Mountain News and the Seattle Post-Intelligencer}

The closures of the Seattle Post-Intelligencer (PI) and the Rocky Mountain News (Rocky) were prompted by a simple factor: insufficient revenue. ${ }^{2}$ From 2006 to 2009, annual nationwide newspaper advertising revenue dropped from about $\$ 49$ billion to $\$ 27$ billion (PEJ, 2012). The migration of audiences to new media gave advertisers many new placement options; meanwhile, newspapers failed to monetize their developing digital audiences as their print circulation revenue eroded. During 2008, the PI lost about \$14 million and the Rocky lost about \$16 million (DeBruin \& Ryckman, 2009; Richman \& James, 2009). Both newspapers were alternately competing and collaborating - via a joint-operating agreement (JOA) - with a second daily newspaper in their home market: The Denver Post and The Seattle Times. Though the PI and Rocky had both been community fixtures for 150 years, their large, national corporate owners E.W. Scripps (Rocky) and Hearst (PI) - no longer saw a future in publishing the second paper in a two-paper market.

[Table 1 about here]

The sudden collapse of advertising revenue immediately precipitated the newspapers' closures - but a long-term decline in circulation was the underlying culprit. By the end of 2009, daily newspaper circulation was down about 31\% from its peak levels nationwide (PEJ, 2010). In Denver, circulation decreases at the two newspapers were similar to nationwide trends: down steadily during the early 2000s and then sharply in 2007-2009 (PEJ, 2010). As Table 1 shows, the Rocky's circulation declined nearly in lockstep with the Post's in the years preceding its closure. By the spring of 2009, both papers had about 203,000 subscribers - but the Post had more active local ownership, favorable union contracts, and lower overhead (Diddlebock, 2009).

\footnotetext{
${ }^{2}$ Technically, the $P I$ lives on as an ad-supported website with a vastly reduced staff.
} 
Ultimately, the Post was the stronger of the two newspapers and its owner was more determined to stay the course.

In Seattle, the figures depart some from the national narrative. Though overall circulation was in decline, the decrease was not as pronounced as it was in Denver or nationally. The key event in the two papers' recent relationship was the Times' switch in 2000 to morning publication (Bishop \& Richman, 2003). This put the two papers in direct competition for the first time - and started a migration of PI subscribers to the Times. This competitive shift also soured the JOA that the two papers had, and the Times moved to end the relationship in 2003 (Bishop \& Richman, 2002; Pryne, 2007). For the next five years, a group of citizens known as the Committee for a Two Newspaper Town fought the dissolution of the JOA in court in the hopes of keeping the PI alive. But, in the end, the JOA issue was moot because Hearst chose to close the $P I$ in the face of mounting losses.

\section{Theorizing Local Newspapers’ Importance}

Several theoretical strands from the past 200 years suggest different ways that newspapers contribute to their communities. In Democracy in America, Tocqueville argues that newspapers were catalysts for the formation of associations that were vital to America's early participatory democracy. Similarly, Bryce (1995) and Tarde (1903) propose that newspapers set common agendas for their readers which, in a way, define the readers' communities. Janowitz (1968) describes the reciprocal relationship between community newspaper readership and community attachment, suggesting that, one way or another, newspaper readership is an important part of being a community member. And, as urban populations suburbanized in the latter half of the 20th century, Kaniss (1997) asserted that large daily newspapers knit patchwork municipalities together into cohesive metropolitan areas by actively cultivating one overarching 
civic identity. But what underpins these related, yet divergent, functions of the local news media?

Habermas, in the Theory of Communicative Action (1985), posits a two-level concept of society that offers a starting point for understanding the relationship between local news media and their communities. He argues that society is structured by both lifeworld - private and public communicative interactions that characterize the daily lives of individuals - and system Weberian economic and state bureaucracies that increasingly delimit these lives (Baxter, 1987). In early societies, these two levels were closely related but, in the $21^{\text {st }}$ century, they are "uncoupling” and the influence of lifeworld upon system is less direct. As the distance between lifeworld and system grows, “media replace linguistic ‘communication' in certain functional contexts, thereby replacing the 'mechanism' of linguistic understanding and consensus” (Baxter, 1987, p. 56). Or, in other words, media become an important link between lifeworld and system.

Communities come into the equation because they are "the complex social structure[s] in which system and lifeworld meet” (Friedland \& McLeod, 1999, p. 198). Though communities may not all be defined by geography and proximity today, local communities are still central to our governance and society (Macedo \& Karpowitz, 2006). But what delineates these communities? Gerrymandered political borders? Mutable incorporations lines? Natural boundaries like rivers or ridges? To these obvious factors, both Tarde (Katz, 1999) and Kaniss (1997) would add local newspapers. They argue that community springs forth from a common agenda that is cultivated by readership of the same newspaper. Friedland and McLeod move beyond readership and argue that, "local media are themselves central institutions connected to other community institutions and operate to link the networks and bonds, in general the set of 
relations, that tie differing associations, subcommunities, and cultures together” (Friedland \& McLeod, 1999, p. 208).

Whether through information dissemination or the work of producing the newspaper, the relations and ties that newspapers contribute to are the basis for public action - which, in modern “uncoupling” societies, is the mechanism through which citizens may influence their system. So, if local media institutions are strong and are binding individuals and groups together, then citizens should be participating in more community groups, contacting their government more frequently, and circulating more petitions because they are more aware of shared problems, interests, and opportunities. ${ }^{3}$ Readership of the same metropolitan newspaper - or other interactions with it - may spur many forms of engagement across districts and boundaries as groups of citizens respond to the same local (or regional) news in different manners. In short, civic engagement and other indicators of an active citizenry should be higher when local news media institutions are numerous and vibrant and members of the public are consuming the content that they produce.

\section{Empirical Evidence of Local Newspapers’ Importance}

Researchers who try to isolate the discrete contributions that newspapers make to their communities typically situate their work somewhere within this broad theoretical foundation. In the process, they have depicted correlations between newspaper readership and civic engagement (Kang \& Kwak, 2003; McLeod, Scheufele, \& Moy, 1999; Moy, McCluskey, McCoy, \& Spratt, 2004; Scheufele, Shanahan, \& Kim, 2002), community attachment (Jeffres, Atkin, \& Neuendorf, 2002; McLeod et al., 1996; Stamm, 1988; Stamm, Emig, \& Hesse, 1997; Stamm \& Weis, 1986), and relevant political outcomes like voters’ local electoral choices (Becker \& Dunwoody, 1982;

\footnotetext{
${ }^{3}$ Another way to say this is that local media provide the communication infrastructure (Kim \& Ball-Rokeach, 2006) for civic engagement to develop.
} 
McLeod et al., 1999). But, most prior research in this vein is limited by a reliance upon crosssectional, single-city datasets that preclude causal tests and limit generalizability (Hoffman \& Eveland, 2010; Kim \& Ball-Rokeach, 2006). Inconsistent, unreliable, and often self-reported media exposure variables, which plague media research in general (Prior, 2009), are an additional obstacle that undermines researchers working to show a causal relationship between newspaper readership and community-related outcomes.

Hoffman and Eveland (2010) address some of these shortfalls by using a national panel study to assess the importance of local news media use. Their findings replicate the wellestablished correlational relationship between local newspaper readership and community attachment, but they do not locate evidence of a significant relationship over time. This prevents any conclusions regarding the causal ordering of the relationship between local news media use and community attachment. In explaining their null findings, Hoffman and Eveland assert that levels of both local news media use and community attachment are entrenched and unlikely to vary much over the course of a year (the time period between the waves of their survey) - unless a dramatic event disrupts the status quo. As they write, "Only panel studies that track individuals over time, beginning when they enter communities or when communities are significantly disrupted by outside events, are likely to be capable of sorting out the causal ambiguities inherent in this area of great theoretical interest" (Hoffman \& Eveland, 2010, p. 193).

It is a pair of such disruptions - the deaths of the PI and Rocky - that prompts the current article. And, there is a small tradition of similar research that informs this work. Berelson (1948) conducted an interview-based examination of the effects of a newspaper delivery strike in New York City that took place in 1945 and lasted for 17 days. In this pre-television era, most of the respondents said they missed the hard news that their newspaper provided - but in Berelson's 
estimation, only about a third were able to engage in enough discussion of the news to indicate that they ever actually read it. More recently, a pair of studies replicated Berelson's work in small towns where the local newspaper was not delivered on a given day (Bentley, 2001) or was permanently shuttered (Smethers, Bressers, Willard, Harvey, \& Freeland, 2007). Like Berelson, both projects found that many of the interviewees primarily missed their newspaper for reasons related to habit or entertainment - but not because of a lack of access to hard news.

If individual-level media exposure variables derived from surveys are unreliable, perhaps a better approach to assessing the importance of newspapers is to use environmental differences to, in effect, establish a natural experiment at the community level. For example, Mondak (1995) compared residents of Pittsburgh during an 8-month long newspaper strike during 1992 and 1993 with residents of Cleveland who did not experience a disruption in their newspapers. He found that there was evidence that the lack of newspapers had a deleterious effect upon Pittsburghers' local political knowledge and talk, but not their national or international political knowledge and talk. So, even without individual-level media exposure variables, it may be possible to measure the effects of access to different media within and across communities.

A recent study of Cincinnati and its suburbs (Schulhofer-Wohl \& Garrido, 2011) that evaluated the effects of the 2007 closure of The Cincinnati Post also uses this kind of community-level approach. The authors suggest that a number of negative political outcomes could be observed from 2007-2010 in the Northern Kentucky communities that the Post traditionally served. These same outcomes, however, were not visible in the communities served by the Cincinnati Enquirer, which did not close. In the Kentucky communities, "Fewer people voted in elections for city council, city commission, and school board; fewer candidates sought those seats; the remaining candidates spent less money on their campaigns; and, for councils and 
commissions, incumbents' chances of retaining office improved” (Schulhofer-Wohl \& Garrido, 2011, p. 2). Even though the Enquirer increased coverage of Northern Kentucky to compensate for the Post's closure, the communities suffered significant, negative local political effects.

Three conclusions emerge from the body of previous empirical scholarship concerning the importance of local newspapers. First, there is an array of evidence that depicts a correlation between local newspaper readership and a variety of important civic, political, and community outcomes. These correlations offer general support for the theoretical arguments that claim newspapers are important to citizens and their communities. Second, because of data and methodological limitations, the causality and generalizability of these relationships is unclear: does newspaper readership spur civic engagement, political action, or community attachment or vice versa? Third, prior research suggests that it may be possible to gain some leverage on both the causality and generalizability of newspapers’ importance by strategically using community-level data.

Hypotheses

In response to the methodological limitations of much of the prior research regarding the importance of local news media - and following the innovative structure of several other projects - this analysis focuses on a community-level comparison of the change in civic engagement in two dozen cities across the United States over a 12-month period. Given prior findings (Hoffman \& Eveland, 2010; Kang \& Kwak, 2003; Moy et al., 2004), the first hypothesis that this article tests is:

\section{H1: A positive association between newspaper readership and acts of civic engagement exists at the national level and within individual communities.}

If this is true, then there is reason to investigate the change in year-over-year civic engagement in various American metropolitan areas, with a particular focus on Denver and 
Seattle. Though cross-sectional data cannot alone establish the causal direction of the relationship between newspaper readership and civic engagement, the tradition of correlational findings suggests that the loss of a newspaper will negatively impact civic engagement:

H2: Civic engagement in Seattle and Denver will decline from 2008 to 2009

Meanwhile, in cities that did not experience a significant disruption in their local media environments, at first blush there is no reason to expect a significant year-over-year change in civic engagement:

H3: Civic engagement in cities other than Seattle and Denver will be unchanged from 2008 to 2009.

At the national level, the demise of the Post-Intelligencer and Rocky Mountain News are relatively insignificant. But, because of the timing of the CPS survey - the 2008 iteration immediately followed the surge of political activity tied to the 2008 presidential campaign and the 2009 iteration was not preceded by a similar catalyst - it is conceivable that civic engagement would be broadly depressed in any year-over-year comparison. Accordingly:

H4: Nationwide, civic engagement will decline from 2008 to 2009.

Finally, even if there is evidence of a national decrease in civic engagement in 2009, an off-election year during an economic downturn, the common factors that contribute to this general decline will be present in Denver and Seattle - and compounded by the loss of newspapers in these cities. With this in mind:

H5: Declines in civic engagement in Seattle and Denver will be larger than declines observed at the national level or in other major American cities due to the closure of a newspaper.

$\underline{\text { Method }}$

The primary dataset in this article merges measures drawn from the 2008 and 2009 November supplements to the CPS. Starting in 2008, the US Census added a battery on civic 
engagement to the CPS that initially included 25 items and was asked of nearly 68,000 respondents nationwide (US Census, 2008). The next year, the battery was repeated - but 12 questions were dropped (including a set of news media usage questions) and the number of respondents was reduced to about 21,000 (US Census, 2009). In addition to the civic engagement battery, the CPS datasets both provide access to basic demographic information describing the respondents and a group of items focused on social capital. ${ }^{4}$

The specific respondents to the CPS vary from year to year , but because the survey population is derived from a probability sample designed to be representative of all households, comparisons of aggregate year-over-year data should be valid. Conducting demographic comparisons of the 2008 and 2009 samples does reveal some significant differences in the metropolitan area populations year-over-year. The differences that do exist are generally muted and may feasibly be attributed to the natural evolution of communities or the nation's macroeconomic environment rather than systematic sampling bias. Table 2 contains a comparison of the 2008 and 2009 sample demographics in Denver and Seattle. There are no significant differences in the sample composition year over year in Seattle, but in Denver there is a significant change in the racial composition of the sample.

[Table 2 about here]

Five core civic engagement items are available in both the 2008 and 2009 CPS datasets. These five questions are analyzed individually, recoded into yes (1) and no (0) dummy variables, and also as a cumulative index of civic engagement that averages all five together $(0-1, \mathrm{M}=.12$, $\mathrm{SD}=.20)$. Together, they are the key dependent variables in the analyses below. They are:

\footnotetext{
${ }^{4}$ See Appendix 1 for a full version of the Civic Engagement Supplement questionnaire.
} 
Please tell whether or not you have done any of the following in the last 12 months, that is between November 200X and now:

(1) Contacted or visited a public official - at any level of government - to express your opinion? (Yes/No/DK/Refused)

(2) Bought or boycotted a certain product or service because of the social or political values of the company that provides it? (Yes/No/DK/Refused)

Have you participated in any of these groups during the last 12 months, that is between November 200X and now:

(3) A school group, neighborhood, or community association such as PTA or neighborhood watch groups? (Yes/No/DK/Refused)

(4) A service or civic organization such as American Legion or Lions Club? (Yes/No/DK/Refused)

(5) In the last 12 months, between November 200X and now, have you been an officer or served on a committee of any group or organization? (Yes/No/DK/Refused)

Additionally, of the 13 substantive items that are repeated from year-to-year in the CPS civic engagement supplement, several target indicators of social capital which have, at most, an indirect conceptual connection to newspaper readership. Three of these 5-point ordinal items tracked the frequency of social activities - having a household dinner, talking with neighbors, and doing favors for neighbors - from 1 (not at all) to 5 (basically every day). These questions are averaged into a social capital index $(1-5, \mathrm{M}=3.22$, $\mathrm{SD}=.94)$, used below as a point of comparison for the civic engagement analyses.

The initial regression analyses below establish the basic relationship between newspaper readership and civic engagement at the individual level. For these, the 2008 CPS dataset is used alone because the news media use questions were eliminated from the 2009 survey. ${ }^{5}$ The newspaper readership question on the 2008 survey is:

Please tell me how often you did each of the following during a TYPICAL MONTH in the past year:

\footnotetext{
${ }^{5}$ Basic demographic control variables are also included in the 2008-only regression analyses. These items allow for the discrete importance of newspaper readership to be better assessed. Wording and recodes of these variables can be found in Appendix 1.
} 
Read a newspaper in print or on the Internet - basically every day, a few times a week, a few times a month, once a month, or not at all? ${ }^{6}$

Next, the 2008 and 2009 datasets are merged to allow for community-level analyses that seek to isolate the effect of the newspaper closures in Denver and Seattle. ${ }^{7}$ Since the 2009 data does not offer news media use variables, the critical independent variable in the year-over-year analyses is implied: the change (or lack thereof) in the media environment within each community. Simple t-tests are initially used to assess the significance of the observed changes.

In the combined dataset, the populations of various metropolitan areas are identified according to the Census CBSA FIPS code. The Census's definitions of metropolitan areas are often relatively broad, encompassing multiple contiguous cities and sometimes even spanning across state lines in the process (US Census, 2008). As scholars have argued (Kaniss, 1997), newspapers also transcend municipal borders, so defining the community of study according to these metropolitan areas is intuitive. In addition, this broad definition of communities yields sample sizes that allow for localized year-over-year comparisons to be made with reasonable statistical power. Accordingly, eight comparison cities were chosen with both a purposive and practical reason in mind. First, in terms of culture and demographics some cities are more comparable in nature (Seattle and Portland, for example) than others (Seattle and Houston). Second, the CPS data, though abundant, limits local-level comparisons to only the largest metropolitan areas because of the reduced sample in 2009.

The final analyses are conducted on a novel dataset built from several sources that allows for a more systematic analysis of the importance of newspaper closures. The primary dependent

\footnotetext{
${ }^{6}$ The newspaper readership variable is included in the regression models below as a $0-4$ scale that runs from not at all (0) to basically every day (4).

${ }^{7}$ The Rocky Mountain News closed on February 27, 2009; the Post-Intelligencer ended its print run on March 17, 2009. Consequently, the timing of the CPS works very well to capture a before and after snapshot of civic engagement in Denver and Seattle.
} 
variable in these models comes from the merged 2008/2009 CPS dataset and is the year-overyear change in civic engagement for each of the top 20 U.S. metropolitan areas - including Denver (\#12) and Seattle (\#20) - by population according to the 2008 CPS. For each city, the index of civic engagement (described above) in 2009 is subtracted from the index of civic engagement in 2008. The same process is completed for the social capital index outlined above, and the difference in social capital is used as an alternate dependent variable.

The year that passed between November, 2008 and November, 2009 was eventful and three key control variables are included in this dataset to address alternate causal explanations for observed changes in civic engagement. A measure of total 2008 political campaign spending on TV advertising for all campaigns combined, by media market, is drawn from data provided by the Wisconsin Advertising Project (Goldstein, Niebler, Neiheisel, \& Holleque, 2011). Newspaper circulation reports from the Audit Bureau of Circulations are used to create a variable that tracks the percentage change in the total circulation of all major dailies present in each of the top 20 cities from the final quarter of 2008 to the final quarter of 2009. Finally, the percentage change in unemployment levels from November, 2008 to November, 2009 by metropolitan area is gleaned from reports made available by the U.S. Bureau of Labor Statistics.

[Table 3 about here]

$\underline{\text { Results }}$

Table 3 contains the results of three OLS regressions that predict cumulative civic engagement in three populations: the United States, Seattle, and Denver. At the national level, the sample is over 50,000 and every IV has a significant relationship with civic engagement, including newspaper readership $(\beta=.014, \mathrm{p} \leq .001)$. In both Denver and Seattle, the positive relationship between newspaper readership and civic engagement holds even with a sample of 
just over 500 ( $\beta=.015, \mathrm{p} \leq .05)$. So, the data confirm H1: there is a positive relationship between newspaper readership and civic engagement.

Table 4 contains the results of year-over-year comparisons of the five civic engagement indicators earlier described. Data for ten cities, including Denver and Seattle, as well as the nation as a whole are reported. Each cell contains the difference from 2008 to 2009, in terms of percent, in the proportion of the survey sample within each metropolitan area that responded in the affirmative to the particular engagement question at hand. Negative numbers indicate that the percentage of respondents who reported taking a specific action declined year-over-year; positive figures indicate the opposite. The significance of each difference was assessed with simple, twotailed t-tests.

[Table 4 about here]

The results show that, in Denver, four of the five civic engagement indicators declined significantly from 2008 to 2009. In Seattle, two of the five indicators decreased significantly over the same period. The other indicators in both cities were not significantly different yearover-year. Together, these results offer support for H2: many measures of civic engagement in Seattle and Denver declined from 2008 to 2009. Overall, aggregate civic engagement declined significantly in Denver $(-4.6 \%, \mathrm{p} \leq .05)$ but not in Seattle $(-1.4 \%)$. As the scaling in Figure 1 shows, the declines in both cities outstripped declines (or increases) in their closest peer cities. ${ }^{8}$ So, although civic engagement declined $4.6 \%$ in absolute terms in Denver, relatively speaking, there was about 30\% less civic engagement in 2009 than 2008.

[Figure 1 about here]

\footnotetext{
${ }^{8}$ See Appendix Table 1 for aggregate civic engagement and social capital change for the top 20 CPS cities.
} 
Meanwhile, in the other eight cities, 35 of the 40 year-over-year comparisons are nonsignificant. Only one indicator across all of the cities - boycotts of products or services among Cincinnatians - significantly declined year-over-year. Four indicators - contacting a public official in Cleveland and Minneapolis, boycotting a product or service in Dallas, and participating in a civic group in Phoenix - increased from 2008 to 2009. So, H3 is not uniformly supported: there are some differences in the data across the nation. But, as $\mathrm{H} 3$ predicts, the vast majority of the city-level indicators were not significantly different across the two years.

The national data in Table 4 provide a wider view. Here, each indicator is significantly different (due in part to the large sample size) in the year-over-year comparisons: four decreased and one increased. The general trend reflects a decline in civic engagement, nationwide, which supports H4. The magnitude of these differences, however, ranges between just 1-2\% across the board. The observed declines in Seattle and Denver, meanwhile, are roughly 5-8\% - which supports H5.

Table 5 presents a more systematic assessment of the effect of newspaper closure upon citizens' civic engagement. In the three models presented, the dependent variable is the aggregate year-over-year change in either social capital or civic engagement. ${ }^{9}$ Though the $\mathrm{N}$ in these models is only 20, the first regression that predicts change in civic engagement is significant $(\mathrm{F}=3.209, \mathrm{p} \leq .05)$ and there is a strong, negative relationship $(\beta=-3.704, \mathrm{p} \leq .01)$ between the closure of a newspaper and civic engagement - even after controlling for the amount of 2008 campaign TV advertising spending in each market and the change in unemployment from 2008 to 2009. Meanwhile, a similar model that predicts change in social capital is not

\footnotetext{
${ }^{9}$ Levels of civic engagement and social capital for the top twenty CPS metropolitan areas are reported in Appendix Table 1. Among these cities, aggregate civic engagement in Seattle was second only to Washington, DC; Denver was fifth overall in civic engagement. The aggregate change in civic engagement in Denver - but not Seattle - is significant. The change in social capital is not significant in either city.
} 
significant; none of the independent variables are significant. Controlling for the year-over-year change in newspaper circulation muddies the picture of civic engagement some. In this model, only the newspaper closure variable is significant $(\beta=-3.571, \mathrm{p} \leq .05)$ - but the regression itself retreats from significance $(\mathrm{F}=2.402, \mathrm{p} \leq .10)$. Together, these models offer further support for $\mathrm{H} 2$ and $\mathrm{H} 5 .^{10}$

[Table 5 about here]

\section{$\underline{\text { Discussion }}$}

The results reported here suggest that the collapse of the Rocky Mountain News and PostIntelligencer adversely affected the civic engagement of citizens in Denver and Seattle. There are many possible explanations for these results: measurement error, chance, and an array of unmeasured factors that may have intervened in the year between measurements. In isolation, it would be difficult to rule out these competing hypotheses and attribute the change to the downfall of a pair of newspapers.

Yet, the data presented here are not in isolation - there are multiple points of comparison that can be used to address alternate explanations. National data suggests that there was a slight decline in many civic engagement indicators from 2008 to 2009 - not surprising considering the change in the macro-political environment. But the magnitude of the decline in Seattle and Denver outstripped the national trend. And, in other, similar cities, measurement of the same indicators, collected in the same surveys, at the same times, showed little evidence of decline.

\footnotetext{
${ }^{10}$ Models that include a variable that reflects the change in non-white population in each city from 2008 to 2009 were also run (see Appendix Table 2). Table 3 shows that, at the national level, non-white respondents report significantly lower civic engagement than white respondents. Since there were significantly more non-white residents of Denver in the 2009 CPS civic engagement sample (Table 2), it is possible that a decline in the level of civic engagement could be explained by this population shift - though there was no significant relationship between race and civic engagement in the 2008 Denver regression in Table 3 . When the variable tracking the change in nonwhite populations was included in regressions predicting the change in civic engagement, it was consistently nonsignificant and the significant, negative effect for newspaper closure held.
} 
Contrasting the Denver and Seattle results with those from like cities offers a pair of important benefits. First, concern that a measurement issue that systematically skewed the data towards a year-over-year decline is assuaged. Second, national-level third variables (economic turmoil, different political conditions, etc.) that could plausibly explain variation in any one city should also cause the same variation in other cities as well. The absence of uniformity across the cities suggests that differences within a city from year-to-year can be attributed to factors at the metropolitan level.

Is it possible that the declines in civic engagement in Seattle and Denver could be the result of factors other than the newspaper closures? Yes. In the 12-month period between surveys, many important and unique events surely transpired in each city in the nation. Yet, as prior research suggests (Kang \& Kwak, 2003; Mondak, 1995; Moy et al., 2004), because newspaper readership is significantly related to civic engagement, it seems very likely that the newspaper closures would bear negatively upon civic engagement in Denver and Seattle. And, even after controlling for the possibility of a spillover effect upon civic engagement caused by greater political advertising in some cities compared to others, the likelihood that the economic downturn that began in 2008 had a depressing effect upon civic engagement, and the ongoing decline of newspaper circulations, the data suggest that the closure of a newspaper still had a measurable effect upon citizen engagement. Finally, models that control for differences in the racial composition of the year-over-year CPS samples suggest that this factor is not related to the change in civic engagement. $^{11}$

Perhaps the observed decline in Denver and Seattle was a chimera: it is conceivable that the estimate of civic engagement in the 2008 CPS data was spuriously high. If this is the case,

\footnotetext{
${ }^{11}$ See Appendix Table 2.
} 
then the 2009 results would merely reflect regression to the mean, and the change from 2008 to 2009 would not be meaningful. Because the CPS civic engagement module began in 2008, it is difficult to address this concern. But, in perhaps the most comparable prior research, The Saguaro Seminar's multi-city social capital benchmark surveys in 2000, civic engagement in Denver and Seattle significantly outstrips civic engagement in the nation as a whole. ${ }^{12}$ This implies that the high reading in 2008 was not aberrant, and the decline from 2008 to 2009 was not random in nature.

If the year-over-year decline is real, perhaps it is only temporary. Data from the 2010 CPS lends some support to this notion. ${ }^{13}$ In 2010, civic engagement rebounded in Denver: it increased significantly $(+3.4 \%, \mathrm{p}<.05)$ though it did not reach its 2008 level. In Seattle, there was a small non-significant decline from 2009-2010, continuing the trend from the year before. Additional years of CPS data will offer two advantages: more case cities (in which newspapers have closed) and more data points to track trends over time. A long term study building on the current research is a worthy future direction. For now, this preliminary result offers some context: the negative effect of newspaper closures reported here may be only a short-term effect as communities develop new ways of producing and accessing information.

Though Denver and Seattle both experienced a similar shock to their local media environments, neither the disruption nor its effects were identical. Clearly, the data show that the magnitude of the negative effect was greater in Denver than in Seattle. Two clear explanations for this divergence come to mind. First, the relative importance of the two newspapers to their

\footnotetext{
${ }^{12}$ In 2000, the Saguaro Seminar coordinated surveys of social capital and civic engagement in 40 communities across the country using the same instrument. This survey includes items very similar to four of the five civic engagement indicators used as dependent variables in this study - the omitted item is the question about contacting a local official. See Appendix Table 3 for simple results of this comparison.

${ }^{13}$ See Appendix Table 1 for civic engagement and social capital levels from 2008 to 2010.
} 
communities was different in at least one key respect: in Seattle, about $8 \%$ of households received the $P I$ while, in Denver, about $20 \%$ of households received the Rocky. Accordingly, we should expect to see larger effects in Denver. Second, the PI halted its print edition but continued to produce and distribute news on the web; meanwhile, the Rocky went completely out of business. If we think of local news as a public good - something that is broadly beneficial even if it is not specifically consumed - then this is an important distinction (Baker, 2001). In Seattle, at least some of the news produced for a print edition of the PI is now created for the web. Even if the audience is for the online edition is smaller, the positive externalities of the news it creates may still exist. In Denver, the amount of local news was simply reduced.

This raises another compelling theoretical question: is the decline of civic engagement driven by a decrease in the production of news or a decrease in the consumption of it? Perhaps Denver and Seattle, as they lost their second newspaper, simply retreated to the level of other one-newspaper towns. If this is the case, then it would imply that decreased production of news was the critical shift. Simple analyses show that civic engagement in the one- and twonewspaper top-20 metropolitan areas is statistically indistinguishable. ${ }^{14}$ Looking at the top-50 metropolitan areas, it appears that civic engagement is significantly higher in one-paper markets - but this comparison is conflated by the fact that the one-newspaper communities tend to be smaller. At least as far back as Tönnies (1957), researchers have theorized that social ties are stronger in smaller communities. In the regressions reported above, however, overall circulation is included as a term to test the importance of readership. It is non-significant - which undermines the notion that readership matters. Again, this questions warrants further research as the current research does not yield a satisfying answer.

\footnotetext{
${ }^{14}$ See Appendix Table 4.
} 
In sum, the evidence reported here implies that Seattle and Denver suffered significant negative declines in civic engagement when they lost one of their daily newspapers. But, perhaps the causal ordering of this relationship is reversed: it is possible that the newspapers were no longer viable because of apathy or weak civic engagement in these communities. The available contextual evidence undermines this perspective. The decline in newspaper circulation in Denver and Seattle was no worse than the nationwide trends. Levels of civic engagement in the communities were high, relative to the top 20 cities, in 2008 - but this was consistent with prior measurements. And in Seattle, a community organization formed explicitly to fight the demise of the $P I$ in court years before its eventual closure. In the end, the PI and Rocky were victims of economics in a changing media environment: very few cities can support two local newspapers, no matter what their civic value may be.

\section{$\underline{\text { Limitations }}$}

This study has several limitations, both in terms of its macro-level conceptualization and micro-level operationalization. Taking a wide view, perhaps the most significant limitation is the fact that no two cities are entirely alike. To a certain extent, this limits the utility of cross-city comparisons. Additionally, the data utilized in these analyses is parsed at the metropolitan level perhaps an overly inclusive approach for measuring the influence of an urban newspaper.

Metropolitan areas are richly varied and working with city-units that correspond more closely to the newspapers’ distribution areas might capture their influence more precisely. But, as Kaniss (1997) suggests, major metropolitan papers make waves beyond urban borders.

In addition, the actual analyses in this study are undermined by a pair of specific drawbacks in the available data. First, the 2009 survey does not contain a newspaper readership item, which means that readership cannot be used as a control in the comparisons. Second, there 
are some minor variations in the demographic profiles of the city-level samples from year to year. These variations could be the source of any observed differences in the year-over-year comparisons. Analyses conducted at the community and group-level overcome these limitations - but without individual-level data, some questions cannot be answered. Additionally, though the study has two time points and two key cities, any year-over-year change could be aberrant and not indicative of a trend or effect. Given data over a longer period, other cities that lost a newspaper could be added to the treatment group and civic engagement could be studied over a greater number of years. Preliminary analysis of the 2010 CPS data suggests that a follow-up study will yield additional insights.

Still, the study presented here has many advantages when compared to similar studies of localized civic engagement. Rather than a single city, cross-sectional design, the CPS data allows for year-over-year within and across city comparisons. Because of this, the study provides a unique illumination of civic engagement as well as the importance of newspapers to their communities. The quasi-experimental design employed here has its drawbacks, but as Mondak puts it, with this approach “...internal and external validity are maximized within a single research design, linking the two threads that have threatened to unravel so many previous studies of the electoral significance of news media” (1995, p. 2). The results here are not causally definitive, but they are a significant contribution to the existing body of literature regarding the importance of local media.

\section{$\underline{\text { Conclusion }}$}

For generations, newspapers have been many things to many people: tool, companion, protector, amusement, and so on. That newspapers are important to their readers and communities should be self-evident - but scholars have struggled to prove this empirically. This 
study suggests that the value of newspapers, even in their current reduced economic and physical state, can be observed - though perhaps only after their demise. A common refrain from new media pundits is that newspapers are not important per se. Rather, news is important - and it can be delivered more efficiently electronically. In terms of distribution, this is clearly true. But the story may be different when the nuances of the transition from analog to digital media are considered. In a newspaper, news is literally on top; on the internet, news may be easily overwhelmed by the preponderance of other content. In addition, metropolitan newspapers are inherently local and their presence is a tie between lifeworld and system in their communities. This triangulation between lifeworld, system, and physical place is not necessarily replicated by digital media. And, as dead newspapers are replaced over time by new media, it is possible that citizens’ relationships with each other and their society will fundamentally change as well.

So how important are newspapers? The results in this article suggest that eliminating a local newspaper from a community leads to less civic engagement in the immediate aftermath among the citizens of that community. How citizens replace that newspaper, and what the contours of civic engagement look like going forward, are questions for future researchers. The advent of new communication opportunities suggests that new forms of engagement will also develop. Thus far, there are many questions about the importance of place online: why should any one place matter when we may all be virtual and interconnected? And yet, our society is still geographically organized and governed. Ultimately, if we desire healthy and productive democratic communities, then the provisioning of local news - which helps tie citizens to each other and their communities - must continue. Newspapers like the PI and Rocky may be gone, but a commitment to local news and information cannot be abandoned. 
Table 1: Circulation of Denver and Seattle Newspapers, 2004-2009

The Denver Post

Rocky Mountain News

The Seattle Times

Seattle Post-Intelligencer

\begin{tabular}{rrrrrr}
$\mathbf{2 0 0 4}$ & $\mathbf{2 0 0 5}$ & $\mathbf{2 0 0 6}$ & $\mathbf{2 0 0 7}$ & $\mathbf{2 0 0 8}$ & $\mathbf{2 0 0 9}$ \\
\hline 286,198 & 268,004 & 255,452 & 254,058 & 225,193 & 203,045 \\
286,003 & 267,031 & 255,427 & 253,834 & 225,066 & 203,021 \\
237,303 & 233,268 & 220,734 & 219,722 & 220,863 & 195,311 \\
150,901 & 144,836 & 131,769 & 128,012 & 129,563 & 116,950 \\
\hline
\end{tabular}

All figures from annual spring reports from the Audit Bureau of Circulation. 
Table 2: Denver and Seattle Sample Demographics, 2008-2009

\begin{tabular}{|c|c|c|c|c|}
\hline & \multicolumn{2}{|c|}{ Seattle } & \multicolumn{2}{|c|}{ Denver } \\
\hline & 2008 & 2009 & 2008 & 2009 \\
\hline \multicolumn{5}{|l|}{ Race } \\
\hline White & $76.2 \%$ & $74.2 \%$ & $77.4 \%$ & $71.1 \%$ \\
\hline Black & $3.5 \%$ & $3.4 \%$ & $3.5 \%$ & $3.0 \%$ \\
\hline Other & $20.3 \%$ & $22.5 \%$ & $19.1 \% *$ & $25.9 \% *$ \\
\hline \multicolumn{5}{|l|}{ Gender } \\
\hline Female & $50.9 \%$ & $50.7 \%$ & $51.1 \%$ & $51.7 \%$ \\
\hline Male & $49.1 \%$ & $49.3 \%$ & $48.9 \%$ & $48.3 \%$ \\
\hline Age & 46.7 & 47.2 & 45.6 & 45.3 \\
\hline Household Income (1-4) & 2.7 & 2.6 & 2.6 & 2.8 \\
\hline Education (1-5) & 4.2 & 4.2 & 4.0 & 4.0 \\
\hline $\mathrm{N}$ & 566 & 209 & 593 & 236 \\
\hline
\end{tabular}

Significance derived from year-over-year, two-tailed t-tests. 
Table 3: OLS Regressions Predicting Civic Engagement in 2008 CPS Data

\begin{tabular}{|c|c|c|c|}
\hline & $\begin{array}{c}\text { National } \\
(\mathrm{N}=57,335)\end{array}$ & $\begin{array}{c}\text { Seattle } \\
(\mathrm{N}=535)\end{array}$ & $\begin{array}{c}\text { Denver } \\
(\mathrm{N}=548)\end{array}$ \\
\hline & Coefficient & Coefficient & Coefficient \\
\hline \multicolumn{4}{|l|}{ Race } \\
\hline White & - & - & - \\
\hline \multirow[t]{2}{*}{ Black } & $-0.027 * * *$ & -0.062 & -0.008 \\
\hline & $(0.003)$ & $(0.055)$ & $(0.046)$ \\
\hline \multirow{2}{*}{ Other } & $-0.042 * * *$ & $-0.082 * * *$ & -0.034 \\
\hline & $(0.002)$ & $(0.023)$ & $(0.023)$ \\
\hline \multicolumn{4}{|l|}{ Gender } \\
\hline Female & - & - & - \\
\hline \multirow[t]{2}{*}{ Male } & $-0.013 * * *$ & -0.008 & -0.018 \\
\hline & $(0.002)$ & $(0.018)$ & $(0.017)$ \\
\hline \multirow[t]{2}{*}{ Age } & $0.008 * * *$ & $0.017^{*}$ & $0.017^{*}$ \\
\hline & $(0.001)$ & $(0.008)$ & $(0.007)$ \\
\hline \multicolumn{4}{|l|}{ Household Income } \\
\hline $1:<\$ 30,000$ & - & - & - \\
\hline \multirow[t]{2}{*}{$2: \$ 30-60,000$} & $0.015 * * *$ & 0.006 & $0.054 *$ \\
\hline & $(0.002)$ & $(0.029)$ & $(0.026)$ \\
\hline \multirow[t]{2}{*}{ 3: $\$ 60,001-\$ 100,000$} & $0.035 * * *$ & 0.009 & $0.090 * * *$ \\
\hline & $(0.002)$ & $(0.028)$ & $(0.025)$ \\
\hline \multirow[t]{2}{*}{ 4: $>\$ 100,000$} & $0.049 * * *$ & $0.059 *$ & $0.080^{* *}$ \\
\hline & $(0.003)$ & $(0.029)$ & $(0.028)$ \\
\hline \multicolumn{4}{|l|}{ Education } \\
\hline 1: < High School & - & - & - \\
\hline \multirow[t]{2}{*}{ 2: High School } & $0.008 * * *$ & 0.008 & 0.018 \\
\hline & $(0.003)$ & $(0.042)$ & $(0.034)$ \\
\hline \multirow[t]{2}{*}{ 3: Some Post-Secondary } & $0.060 * * *$ & $0.084^{*}$ & 0.046 \\
\hline & $(0.003)$ & $(0.041)$ & $(0.033)$ \\
\hline \multirow[t]{2}{*}{ 4: College } & $0.107 * * *$ & $0.105^{*}$ & $0.091 * *$ \\
\hline & $(0.003)$ & $(0.042)$ & $(0.034)$ \\
\hline \multirow[t]{2}{*}{ 5: > College } & $0.161^{* * *}$ & $0.210 * * *$ & $0.156 * * *$ \\
\hline & $(0.004)$ & $(0.046)$ & $(0.040)$ \\
\hline \multirow[t]{2}{*}{ Newspaper Readership (0-4) } & $0.014 * * *$ & $0.015^{*}$ & $0.015^{*}$ \\
\hline & $(0.001)$ & $(0.007)$ & $(0.006)$ \\
\hline \multirow[t]{2}{*}{ Intercept } & 0.001 & -0.015 & -0.044 \\
\hline & $(0.004)$ & $(0.050)$ & $(0.042)$ \\
\hline $\mathrm{R}^{2}$ & 0.135 & 0.173 & 0.159 \\
\hline $\mathrm{F}$ & $748.504 * * *$ & $9.076 * * *$ & $8.414 * * *$ \\
\hline
\end{tabular}


Table 4: \% Change in 5 Civic Engagement Indicators from 2008 to 2009, by City

\begin{tabular}{|c|c|c|c|c|c|c|}
\hline & $\mathrm{N}$ & $\begin{array}{c}\text { 1: } \\
\text { Contact Public } \\
\text { Official }\end{array}$ & $\begin{array}{c}2: \\
\text { Boycott } \\
\text { Product or } \\
\text { Service } \\
\end{array}$ & $\begin{array}{c}\text { 3: } \\
\text { Neighborhood } \\
\text { Group } \\
\text { Membership }\end{array}$ & $\begin{array}{c}\text { 4: } \\
\text { Civic Group } \\
\text { Membership }\end{array}$ & $\begin{array}{c}5: \\
\text { Act as a } \\
\text { Group Officer }\end{array}$ \\
\hline Denver & $\begin{array}{l}2008=589 \\
2009=236\end{array}$ & $-5.11 \% *$ & $-8.53 \% * *$ & $0.59 \%$ & $-4.85 \% *$ & $-4.67 \% *$ \\
\hline Seattle & $\begin{array}{l}2008=563 \\
2009=209\end{array}$ & $5.90 \%$ & $-6.71 \% *$ & $1.95 \%$ & $-1.01 \%$ & $-6.83 \% *$ \\
\hline Cincinnati & $\begin{array}{l}2008=294 \\
2009=130\end{array}$ & $-2.42 \%$ & $-7.37 \% *$ & $-5.28 \%$ & $2.18 \%$ & $-3.81 \%$ \\
\hline Cleveland & $\begin{array}{l}2008=304 \\
2009=103\end{array}$ & $7.59 \% *$ & $-3.80 \%$ & $-1.66 \%$ & $-2.76 \%$ & $-6.70 \%$ \\
\hline Dallas & $\begin{array}{l}2008=824 \\
2009=246\end{array}$ & $3.83 \%$ & $4.70 \% *$ & $-1.95 \%$ & $-0.46 \%$ & $0.64 \%$ \\
\hline Minneapolis & $\begin{array}{l}2008=970 \\
2009=260\end{array}$ & $5.75 \% *$ & $4.43 \%$ & $2.08 \%$ & $1.13 \%$ & $-1.09 \%$ \\
\hline Philadelphia & $\begin{array}{c}2008=1349 \\
2009=419\end{array}$ & $-1.12 \%$ & $-0.21 \%$ & $0.00 \%$ & $-0.87 \%$ & $-0.06 \%$ \\
\hline Phoenix & $\begin{array}{l}2008=456 \\
2009=177\end{array}$ & $2.87 \%$ & $-0.92 \%$ & $-1.50 \%$ & $3.59 \% *$ & $-0.10 \%$ \\
\hline Portland & $\begin{array}{l}2008=524 \\
2009=176\end{array}$ & $1.76 \%$ & $-0.08 \%$ & $-0.38 \%$ & $-2.73 \%$ & $-1.20 \%$ \\
\hline San Francisco & $\begin{array}{l}2008=510 \\
2009=227\end{array}$ & $0.42 \%$ & $-0.25 \%$ & $-0.99 \%$ & $3.03 \%$ & $1.80 \%$ \\
\hline Nationwide & $\begin{array}{l}2008=68042 \\
2009=20840\end{array}$ & $1.06 \% * * *$ & $-1.43 \% * * *$ & $-1.78 \% * * *$ & $-0.96 \% * * *$ & $-1.32 \% * * *$ \\
\hline
\end{tabular}

$* \mathrm{p} \leq .05 * * \mathrm{p} \leq .01 * * * \mathrm{p} \leq .001$

Significance derived from year-over-year, two-tailed t-tests. 
Table 5: OLS Regressions Predicting Change in Civic Engagement and Social Capital in Top 20 U.S. Cities, 2008-2009

\begin{tabular}{lccc} 
& $\begin{array}{c}\text { Change in } \\
\text { Social Capital }\end{array}$ & $\begin{array}{c}\text { Change in Civic } \\
\text { Engagement } \\
(1)\end{array}$ & $\begin{array}{c}\text { Change in Civic } \\
\text { Engagement } \\
(2)\end{array}$ \\
\hline & Coefficient & Coefficient & Coefficient \\
\hline \% Change in Unemployment & -0.603 & 40.85 & 38.318 \\
& $(2.204)$ & $(35.14)$ & $(36.107)$ \\
2008 Campaign TV Spending & 0.001 & $0.001^{*}$ & 0.001 \\
& $(0.001)$ & $(0.001)$ & $(0.001)$ \\
Newspaper Closure Dummy & 0.143 & $-3.704^{* *}$ & $-3.571^{*}$ \\
& $(0.080)$ & $(1.269)$ & $(1.314)$ \\
\% Change in Newspaper Circulation & - & - & 0.027 \\
& & & $(0.045)$ \\
Intercept & -0.105 & $-2.701^{*}$ & -2.191 \\
& $(0.074)$ & $(1.187)$ & $(1.479)$ \\
$\mathrm{R}^{2}$ & & & \\
$\mathrm{~F}$ & 0.236 & 0.376 & 0.390 \\
$\mathrm{~N}=20 . * \mathrm{p} \leq .05 * * \mathrm{p} \leq .01$ & 1.645 & $3.209^{*}$ & 2.402 \\
\hline
\end{tabular}


Figure 1: \% Relative Change in Civic Engagement, 2008-2009

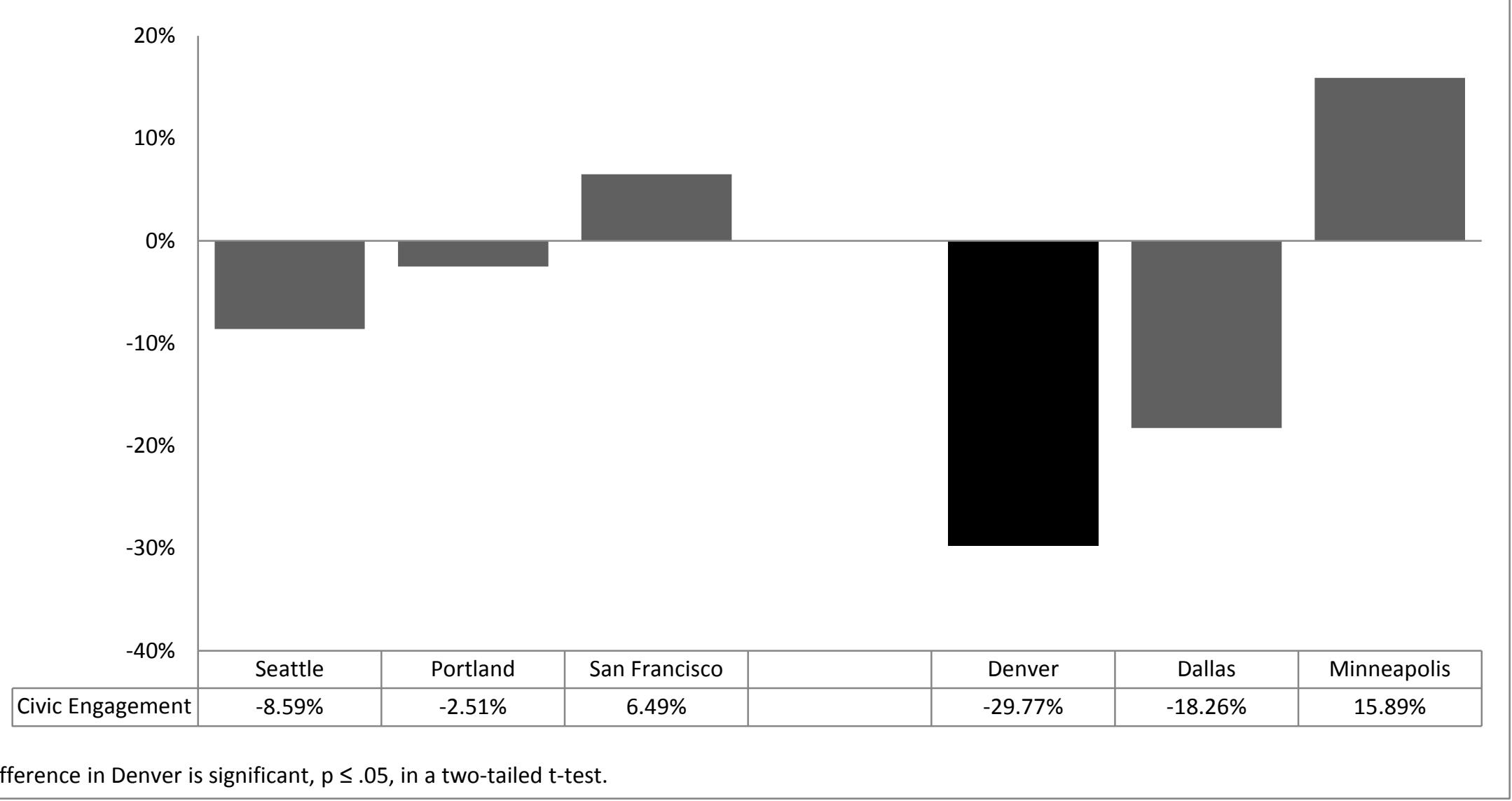




\section{Bibliography}

Baker, C. E. (2001). Media, Markets, and Democracy. Cambridge University Press.

Baxter, H. (1987). System and Life-World in Habermas's “Theory of Communicative Action.” Theory and Society, 16(1), 39-86.

Becker, L. B., \& Dunwoody, S. (1982). Media Use, Public Affairs Knowledge And Voting in a Local Election. Journalism Quarterly, 59(2), 212-255.

Bentley, C. (2001). No Newspaper Is No Fun--Even Five Decades Later. Newspaper Research Journal, 22(4), 2.

Berelson, B. (1948). What “Missing the Newspaper” Means. In P. F. Lazarsfeld \& F. N. Stanton (Eds.), Communication Research (1948th-1949th ed., pp. 111-129). New York: Harper \& Brothers.

Bishop, T., \& Richman, D. (2002, October 19). P-I Publisher Says Times Deal Will Be Enforced. Seattle, p. C-1.

Bishop, T., \& Richman, D. (2003, November 4). Times Gains as P-I Declines: Circulation Trend Steady for 3 Years. The Seattle Post-Intelligencer, p. C-1.

Bryce, J. (1995). The American Commonwealth, The: Two Volume CL Set (Vol.1\&2nd ed.). Liberty Fund Inc.

DeBruin, L., \& Ryckman, L. (2009, February 26). Rocky Mountain News to close, publish final edition Friday. Rocky Mountain News. Retrieved from http://www.rockymountainnews.com/news/2009/feb/26/rocky-mountain-news-closesfriday-final-edition/

Diddlebock, B. (2009, March 6). Who Really Killed the Rocky Mountain News? Time. Retrieved from http://www.time.com/time/business/article/0,8599,1883345,00.html 
Friedland, L. A., \& McLeod, J. M. (1999). Community integration and mass media: A reconsideration. In D. Demers \& K. Viswa (Eds.), Mass media, social control, and social change: A macrosocial perspective (pp. 197-226). Ames: Iowa State University Press.

Goldstein, K., Niebler, S., Neiheisel, J., \& Holleque, M. (2011). Congressional and Gubernatorial Advertising, 2008 ( No. Combined File [dataset]. Initial release.). Madison, WI: The University of Wisconsin Advertising Project, The Department of Political Science at The University of Wisconsin-Madison.

Habermas, J. (1985). The Theory of Communicative Action, Volume 1: Reason and the Rationalization of Society. (T. McCarthy, Trans.). Beacon Press.

Hoffman, L., \& Eveland, W. (2010). Assessing Causality in the Relationship Between Community Attachment and Local News Media Use. Mass Communication and Society, 13(2), 174-195. doi:10.1080/15205430903012144

Janowitz, M. (1968). Community Press in an Urban Setting (2nd Revised ed.). University of Chicago Press.

Jeffres, L. W., Atkin, D., \& Neuendorf, K. A. (2002). A Model Linking Community Activity and Communication With Political Attitudes and Involvement in Neighborhoods. Political Communication, 19(4), 387. doi:10.1080/01957470290055574

Kang, N., \& Kwak, N. (2003). A Multilevel Approach to Civic Participation. Communication Research, 30(1), 80 -106. doi:10.1177/0093650202239028

Kaniss, P. (1997). Making Local News. University Of Chicago Press.

Katz, E. (1999). Theorizing Diffusion: Tarde and Sorokin Revisited. Annals of the American Academy of Political and Social Science, 566, 144-155. 
Kim, Y. C., \& Ball-Rokeach, S. J. (2006). Civic Engagement From a Communication Infrastructure Perspective. Communication Theory, 16(2), 173-197. doi:10.1111/j.14682885.2006.00267.x

Macedo, S., \& Karpowitz, C. F. (2006). The Local Roots of American Inequality. PS: Political Science \& Politics, (January), 59-64.

McLeod, J. M., Daily, K., Guo, Z., Eveland, W. P., Bayer, J., Yang, S., \& Wang, H. (1996). Community Integration, Local Media Use, and Democratic Processes. Communication Research, 23(2), 179 -209. doi:10.1177/009365096023002002

McLeod, J. M., Scheufele, D. A., \& Moy, P. (1999). Community, Communication, and Participation: The Role of Mass Media and Interpersonal Discussion in Local Political Participation. Political Communication, 16(3), 315. doi:10.1080/105846099198659

Mondak, J. J. (1995). Nothing to Read: Newspapers and Elections in a Social Experiment. University of Michigan Press.

Moy, P., McCluskey, M. R., McCoy, K., \& Spratt, M. A. (2004). Political Correlates of Local News Media Use. Journal of Communication, 54(3), 532-546. doi:10.1111/j.14602466.2004.tb02643.x

PEJ. (2010). The State of the News Media 2010. Project for Excellence in Journalism. Retrieved from http://stateofthemedia.org/2010/newspapers-summary-essay/audience/ PEJ. (2012). The State of the News Media 2012. The Pew Research Center's Project for Excellence in Journalism. Retrieved from http://stateofthemedia.org/2012/overview-4/ Prior, M. (2009). The Immensely Inflated News Audience: Assessing Bias in Self-Reported News Exposure. Public Opinion Quarterly, 73(1), 130 -143. doi:10.1093/poq/nfp002 
Pryne, E. (2007, March 7). Committee for a Two-Newspaper Town will have to wait for day in court. Seattle Times. Retrieved from http://seattletimes.nwsource.com/html/localnews/2003605677_webjoa07m.html

Richman, D., \& James, A. (2009, March 16). Seattle P-I to publish last edition Tuesday. Seattle Post-Intelligencer. Retrieved from http://www.seattlepi.com/business/article/Seattle-P-Ito-publish-last-edition-Tuesday-1302597.php

Scheufele, D. A., Shanahan, J., \& Kim, S. H. (2002). Who cares about local politics? Media influences on local political involvement, issue awareness, and attitude strength. Journalism and Mass Communication Quarterly, 79(2), 427-444.

Schulhofer-Wohl, S., \& Garrido, M. (2011, April). Do Newspapers Matter? Short-Run and Long-Run Evidence from the Closure of The Cincinnati Post. NBER Working Paper 686. Retrieved from http://minneapolisfed.org/research/WP/WP686.pdf

Smethers, S., Bressers, B., Willard, A., Harvey, L., \& Freeland, G. (2007). Kansas Readers Feel Loss When Town’s Paper Closes. Newspaper Research Journal, 28(4), 6.

Stamm, K. (1988). Community Ties and Media Use. Critical Studies in Mass Communication, 5(4), 357-61.

Stamm, K., Emig, A. G., \& Hesse, M. B. (1997). The contribution of local media to community involvement. Journalism and Mass Communication Quarterly, 74(1), 97-107.

Stamm, K., \& Weis, R. (1986). The Newspaper and Community Integration. Communication Research, 13(1), 125 -137. doi:10.1177/009365028601300107

Starr, P. (2011). Goodbye to the Age of Newspapers (Hello to a New Era of Corruption):Why American Politics and Society Are About to Be Changed for the Worse. In R. W. 
McChesney \& V. Pickard (Eds.), Will the Last Reporter Please Turn out the Lights: The Collapse of Journalism and What Can Be Done To Fix It (pp. 18-37). New Press, The.

Tarde, G. de. (1903). The laws of imitation. H. Holt and Company.

Tocqueville, A. de. (2001). Democracy in America. Signet Classics.

Tönnies, F., \& Loomis, C. P. (1957). Community \& society (Gemeinschaft und Gesellschaft). East Lansing: Michigan State University Press.

US Census. (2008). Current Population Survey, November 2008 - Civic Engagement Supplement File: Technical Documentation CPS-08. US Census. Retrieved from http://www.census.gov/apsd/techdoc/cps/cpsnov08c.pdf

US Census. (2009). Current Population Survey, November 2009 - Civic Engagement Supplement File: Technical Documentation CPS-09. US Census. Retrieved from http://www.census.gov/apsd/techdoc/cps/cpsnov09c.pdf 


\section{$\underline{\text { Appendix }}$}

\section{United States Census: CPS November Questionnaire}

\section{Demographic Items (2008 and 2009)}

EDUCATION: What is the highest level of school you have completed or the highest degree you have received?

VALID ENTRIES

31 LESS THAN 1ST GRADE

32 1ST, 2ND, 3RD OR 4TH GRADE

33 5TH OR 6TH GRADE

34 7TH OR 8TH GRADE

35 9TH GRADE

36 10TH GRADE

37 11TH GRADE

38 12TH GRADE NO DIPLOMA

39 HIGH SCHOOL GRAD-DIPLOMA OR EQUIV (GED)

40 SOME COLLEGE BUT NO DEGREE

41 ASSOCIATE DEGREE-OCCUPATIONAL/VOCATIONAL

42 ASSOCIATE DEGREE-ACADEMIC PROGRAM

43 BACHELOR'S DEGREE (EX: BA, AB, BS)

44 MASTER'S DEGREE (EX: MA, MS, MEng, MEd, MSW)

45 PROFESSIONAL SCHOOL DEG (EX: MD, DDS, DVM)

46 DOCTORATE DEGREE (EX: PhD, EdD)

Recoded into five dummy variables:

31-38=Less than High School (1)

$39=$ High School (2)

40-42=Some College (3)

$43=$ College $(4)$

44-46=Graduate Degree (5)

RACE: What is your race?

VALID ENTRIES

01 White Only

02 Black Only

03 American Indian, Alaskan Native Only

04 Asian Only

05 Hawaiian/Pacific Islander Only

06 White-Black

07 White-AI

08 White-Asian 
09 White-Hawaiian

10 Black-AI

11 Black-Asian

12 Black-HP

13 AI-Asian

14 Asian-HP

$15 \mathrm{~W}-\mathrm{B}-\mathrm{AI}$

$16 \mathrm{~W}-\mathrm{B}-\mathrm{A}$

$17 \mathrm{~W}-\mathrm{AI}-\mathrm{A}$

$18 \mathrm{~W}-\mathrm{A}-\mathrm{HP}$

19 W-B-AI-A

202 or 3 Races

214 or 5 Races

HISPANIC: Are you Hispanic?

VALID ENTRIES

1 HISPANIC

2 NON-HISPANIC

Recoded into three exclusive dummy variables:

White, not Hispanic

Black, not Hispanic

Other, including all Hispanic groups

SEX: Ask Only If Necessary: What is your sex?

VALID ENTRIES

1 MALE

2 FEMALE

AGE: Person's age as of the end of the survey week.

VALID ENTRIES

00-79 Age in Years

80 80-84 Years Old

85 85+ Years Old

Recoded into six dummy variables:

$18-24=1$

$25-34=2$

$35-49=3$

50-64=4

$65-79=5$

80\&up $=6$ 
FAMILY INCOME: Which category represents the total combined income of all members of this Family during the past 12 months. This includes money from jobs, net income from business, farm or rent, pensions, dividends, interest, social security payments and any other money income received by members of this Family who are 15 years of age or older?

VALID ENTRIES

1 LESS THAN $\$ 5,000$

2 5,000 TO 7,499

37,500 TO 9,999

410,000 TO 12,499

512,500 TO 14,999

615,000 TO 19,999

7 20,000 TO 24,999

8 25,000 TO 29,999

930,000 TO 34,999

1035,000 TO 39,999

11 40,000 TO 49,999

1250,000 TO 59,999

13 60,000 TO 74,999

14 75,000 TO 99,999

15 100,000 TO 149,999

16 150,000 OR MORE

Recoded into four dummy variables:

$1-8=$ Less than $\$ 20,000$ (1)

$9-12=\$ 20-59,999$ (2)

$13-14=\$ 60-99,999$ (3)

$15-16=\$ 100,000$ \&up (4)

\section{Civic Engagement Supplement}

PRESUP2 The next set of questions are about people's involvement and communication within their communities.

2008 AND 2009

Q2 During a TYPICAL MONTH in the past year, when communicating with family and friends, how often were politics discussed -- basically every day, a few times a week, a few times a month, once a month, or not at all?

(1) Basically every day

(2) A few times a week

(3) A few times a month

(4) Once a month 
(5) Not at all

\section{ONLY}

Q3 I am going to read some ways that people get news and information. Please tell me how often you did each of the following during a TYPICAL MONTH in the past year:

(a) Read a newspaper in print or on the Internet - basically every day, a few times a week, a few times a month, once a month, or not at all?

(0) No Internet

(1) Basically every day

(2) A few times a week

(3) A few times a month

(4) Once a month

(5) Not at all

(b) Read news magazines such as Newsweek or Time, in print or on the Internet basically every day, a few times a week, a few times a month, once a month, or not at all?

(1) Basically every day

(2) A few times a week

(3) A few times a month

(4) Once a month

(5) Not at all

(c) Watch the news on television or get news from television internet sites basically every day, a few times a week, a few times a month, once a month, or not at all?

(1) Basically every day

(2) A few times a week

(3) A few times a month

(4) Once a month

(5) Not at all

(d) Listen to the news on radio or get news from radio internet sites - basically every day, a few times a week, a few times a month, once a month, or not at all?

(1) Basically every day

(2) A few times a week

(3) A few times a month

(4) Once a month

(5) Not at all

(e) Obtain news from any other Internet sources that we have not previously asked about such as blogs, chat rooms, or independent news services basically every day, a few times a week, a few times a month, once a month, or 
not at all?
(1) Basically every day
(2) A few times a week
(3) A few times a month
(4) Once a month
(5) Not at all

Q4 I am going to read a list of things some people have done to express their views. Please tell me whether or not you have done any of the following in the last 12 months, that is between November 2007 and now:

2008 AND 2009

(a) Contacted or visited a public official - at any level of government - to express your opinion?
(1) Yes
(2) No

\section{ONLY}

(b) Attended a meeting where political issues are discussed?

(1) Yes

(2) No

8-3

$\underline{2008 \text { AND } 2009}$

(c) Bought or boycotted a certain product or service because of the social or political values of the company that provides it?
(1) Yes
(2) No

\section{ONLY}

(d) Taken part in a march, rally, protest or demonstration?

(1) Yes

(2) No

(e) Showed support for a particular political candidate or party by distributing campaign materials, fundraising, making a donation or in some other way?
(1) Yes
(2) No

Q5 The next questions are about the groups or organizations in which people sometimes participate. I will read a list of types of groups and organizations. Please tell me whether or not you participated in any of these groups during the last 12 
months, that is between November 2007 and now:

2008 AND 2009

(a) A school group, neighborhood, or community association such as PTA or neighborhood watch groups?

(1) Yes

(2) No

(b) A service or civic organization such as American Legion or Lions Club?

(1) Yes

(2) No

(c) A sports or recreation organization such as a soccer club or tennis club?

(1) Yes

(2) No

(d) A church, synagogue, mosque or other religious institutions or organizations, NOT COUNTING your attendance at religious services?

(1) Yes

(2) No

(e) Any other type of organization that I have not mentioned?

(1) Yes [Go to S5s]

(2) No

Q5s What type of organization is that?

2008 AND 2009

Q6 In the last 12 months, between November 2007 and now, have you been an officer or served on a committee of any group or organization?

(1) Yes

(2) No

\section{$\underline{2008 \text { ONLY }}$}

Q7 In the last 12 months, between November 2007 and now, have you attended a meeting of any group or organization?

(1) Yes

(2) No 
Q8 During a TYPICAL MONTH in the past year, how often did you eat dinner with any of the other members of your household -basically every day, a few times a week, a few times a month, once a month, or not at all?

(1) Basically every day

(2) A few times a week

(3) A few times a month

(4) Once a month

(5) Not at all

$\underline{2008 \text { AND } 2009}$

Q9 During a TYPICAL MONTH in the past year, how often, if at all, did you communicate with friends and family by Email or on the Internet -basically every day, a few times a week, a few times a month, once a month, or not at all?

(1) Basically every day

(2) A few times a week

(3) A few times a month

(4) Once a month

(5) Not at all

8-5

2008 AND 2009

Q10 During a TYPICAL MONTH in the past year, how often did you talk with any of your neighbors - basically every day, a few times a week, a few times a month, once a month, or not at all?

(1) Basically every day

(2) A few times a week

(3) A few times a month

(4) Once a month

(5) Not at all

$\underline{2008 \text { AND } 2009}$

Q11 During a TYPICAL MONTH in the past year, how often did you and your neighbors do favors for each other? By favors we mean such things as watching each other's children, helping with shopping, house sitting, lending garden or house tools, and other small acts of kindness -basically every day, a few times a week, a few times a month, once a month, or not at all?
(1) Basically every day
(2) A few times a week
(3) A few times a month 
(4) Once a month

(5) Not at all

\section{ONLY}

Q12 NOT COUNTING family members, about how many CLOSE FRIENDS do you currently have, if any? These are people you feel at ease with, can talk to about private matters, or call on for help.

Number $\longrightarrow$

\section{ONLY}

Q19 People nowadays have a lot to keep up with and no one can keep up with everything. I have two questions about federal laws. If you don't happen to know the answer, just tell me and we'll move on.

(self-response only)

(a) What individual or group of individuals has the responsibility to make the final decision on whether a law is constitutional or not - is it the President of the United States, the Supreme Court, or the Congress?
(1) President of the United State
(2) Supreme Court
(3) Congress
(4) DK
(5) Refused
8-6

(b) Do you know how much of a majority is required for the U.S. Senate and House to override a presidential veto? Is it 80 percent, 67 percent, 60 percent, or 51 percent?
(1) 80 percent
(2) 67 percent
(3) 60 percent
(4) 51 percent 
Appendix Table 1: Levels of Civic Engagement and Social Capital in CPS Top 20 Metropolitan Areas (and Cincinnati)

\begin{tabular}{rlcccccc} 
Size & \multicolumn{1}{c}{ City } & \multicolumn{2}{c}{ Civic Engagement } & \multicolumn{3}{c}{ Social Capital } \\
\hline & & $\mathbf{2 0 0 8}$ & $\mathbf{2 0 0 9}$ & $\mathbf{2 0 1 0}$ & $\mathbf{2 0 0 8}$ & $\mathbf{2 0 0 9}$ & $\mathbf{2 0 1 0}$ \\
\cline { 2 - 7 } 1 & New York City & $8.5 \%$ & $7.9 \%$ & $8.5 \%$ & 3.2 & 3.1 & 3.1 \\
2 & Los Angeles & $9.2 \% *$ & $6.3 \% *$ & $7.4 \%$ & $3.1^{*}$ & $2.9^{*}$ & 3.0 \\
3 & Washington DC & $16.8 \%$ & $15.0 \%$ & $14.1 \%$ & $3.2^{*}$ & $3.0^{*}$ & 3.1 \\
4 & Philadelphia & $11.4 \%$ & $11.0 \%$ & $10.8 \%$ & 3.2 & 3.1 & 3.1 \\
5 & Chicago & $12.3 \%$ & $11.6 \%$ & $10.9 \%$ & $3.2^{*}$ & $3.0^{*}$ & 3.1 \\
6 & Providence & $12.7 \% *$ & $9.9 \% *^{*}$ & $12.1 \%{ }^{\#}$ & 3.2 & $3.2^{\#}$ & $3.0^{\#}$ \\
7 & Boston & $11.4 \%$ & $11.1 \%$ & $11.6 \%$ & $3.2^{*}$ & $3.0^{*}$ & 3.1 \\
8 & Minneapolis & $15.5 \%$ & $17.9 \%{ }^{*}$ & $13.6 \%$ & 3.3 & 3.2 & 3.2 \\
9 & Dallas & $15.5 \%$ & $12.7 \%$ & $10.7 \%$ & 3.1 & 3.0 & 3.0 \\
10 & Atlanta & $12.2 \%$ & $9.6 \%$ & $12.3 \%{ }^{\#}$ & 3.1 & 3.1 & 3.0 \\
11 & Miami & $6.3 \%$ & $5.5 \%$ & $4.9 \%$ & 3.1 & $3.1^{\#}$ & $3.0^{\#}$ \\
12 & DENVER & $15.3 \% *$ & $10.8 \%{ }^{*}$ & $14.2 \%{ }^{\#}$ & 3.1 & 3.2 & 3.1 \\
13 & Houston & $9.2 \%$ & $10.4 \%$ & $9.2 \%$ & 3.3 & 3.1 & 3.2 \\
14 & Baltimore & $14.2 \%$ & $12.1 \%$ & $11.8 \%$ & $3.3^{*}$ & $3.2^{*}$ & 3.2 \\
15 & Honolulu & $9.5 \%$ & $8.2 \%$ & $7.7 \%$ & 3.2 & $3.0^{\#}$ & $3.1^{\#}$ \\
16 & Detroit & $12.6 \%$ & $12.5 \%$ & $10.3 \%$ & $3.3^{*}$ & $3.1^{*}$ & 3.1 \\
17 & Las Vegas & $5.7 \%$ & $5.9 \%$ & $6.3 \%$ & $2.9^{*}$ & $2.8^{*}$ & 2.8 \\
18 & San Francisco & $13.6 \%$ & $14.4 \%$ & $14.1 \%$ & 3.3 & 3.2 & 3.1 \\
19 & Riverside & $7.7 \%$ & $7.7 \%$ & $7.2 \%$ & 3.2 & 3.1 & 3.1 \\
20 & SEATTLE & $16.7 \%$ & $15.2 \%$ & $14.9 \%$ & 3.2 & 3.1 & 3.2 \\
32 & Cincinnati & $12.5 \%$ & $9.3 \%$ & $9.1 \%$ & $3.4^{*}$ & $3.2^{*}$ & 3.2 \\
\hline
\end{tabular}

* Change from 2008-2009 significant, $\mathrm{p} \leq .05$

\# Change from 2009-2010 significant, $\mathrm{p} \leq .05$

Significance derived from year-over-year, two-tailed t-tests. 
Appendix Table 2: Change in Civic Engagement in Top 20 U.S. Cities, 2008-2009, Controlling for Racial Change in Year-Over-Year Samples (OLS Regressions)

\begin{tabular}{lcc} 
& $\begin{array}{c}\text { Change in Civic } \\
\text { Engagement } \\
(1)\end{array}$ & $\begin{array}{c}\text { Change in Civic } \\
\text { Engagement } \\
(2)\end{array}$ \\
\hline \% Change in Unemployment & Coefficient & Coefficient \\
\hline 2008 Campaign TV Spending & 41.14 & 38.84 \\
& $(36.08)$ & $(37.40)$ \\
Newspaper Closure Dummy & $0.001^{*}$ & 0.001 \\
\% Change in Non-White Population & $(0.001)$ & $(0.001)$ \\
& $-3.824^{* *}$ & $-3.655^{*}$ \\
\% Change in Newspaper Circulation & $(1.333)$ & $(1.417)$ \\
& 2.638 & 1.441 \\
Intercept & $(6.221)$ & $(6.897)$ \\
$\mathrm{R}^{2}$ & - & 0.023 \\
$\mathrm{~F}$ & & $(0.050)$ \\
$\mathrm{N}=20 . * \mathrm{p} \leq .05 * * \mathrm{p} \leq .01$ & $-2.787 *$ & -2.312 \\
& $(1.236)$ & $(1.635)$ \\
\end{tabular}


Appendix Table 3: Levels of Civic Engagement in 2000 Saguaro Surveys

\begin{tabular}{lcc} 
& Mean & $\mathbf{N}$ \\
\cline { 2 - 3 } Cincinnati & .145 & 1001 \\
Denver & .199 & 501 \\
Seattle & .205 & 502 \\
\hline All Other Cities & $\mathbf{. 1 6 5}$ & $\mathbf{2 7 2 2 9}$ \\
\hline
\end{tabular}


Appendix Table 4: Civic Engagement in One- and Two-Newspaper Towns

\begin{tabular}{lcccc} 
& $\mathbf{2 0 0 8}$ & $\mathbf{N}$ & $\mathbf{2 0 0 9}$ & $\mathbf{N}$ \\
\cline { 2 - 5 } Top 20 Cities & & & & \\
Denver/Seattle & $15.75 \%^{\mathrm{ab}}$ & 1221 & $12.85 \%{ }^{\mathrm{ab}}$ & 445 \\
1 paper & $11.22 \%^{\mathrm{a}}$ & 7330 & $10.67 \%^{\mathrm{a}}$ & 2176 \\
2 paper & $11.12 \%^{\mathrm{b}}$ & 12032 & $10.14 \%^{\mathrm{b}}$ & 4023
\end{tabular}

Top 50 Cities

Denver/Seattle

1 paper

$15.75 \%{ }^{\mathrm{ab}}$

1221

$12.85 \%^{\mathrm{a}}$

445

2 paper

$12.47 \%{ }^{\text {ac }}$

17217

$11.46 \%^{\mathrm{b}}$

5271

Superscript indicates that difference within year is significant, $\mathrm{p} \leq .01$

4360

Significance derived from two-tailed t-tests. 